Trends in Agriculture \& Life Sciences, Vol. 57, 2019. 12.

농업생명과학연구동향, 제 57 집

https://doi.org/10.29335/tals.2019.57.52

Case Study

$$
\begin{gathered}
\text { 콘크리트 구조물의 사용한계상태 기반 균열제어 } \\
\text { 이기열 }{ }^{1, *} \text { · 김민중 }{ }^{2} \\
{ }^{1} \text { 전남대학교 조경학과, }{ }^{2} \text { 순천제일대학교 토목과 }
\end{gathered}
$$

\title{
Crack Control in Reinforced Concrete Structures Based on Serviceability Limit States
}

\author{
Ki Yeol Lee ${ }^{1, *}$ and Min Joong $\mathrm{Kim}^{2}$ \\ ${ }^{1}$ Department of Landscape Architecture, Chonnam National University \\ ${ }^{2}$ Department of Civil Engineering, Suncheon Jeil College, Suncheon 57997, Korea \\ *Corresponding author: gylee@jnu.ac.kr
}

\begin{abstract}
In order to respond to the international demands that require application of the reliability based limit states design, The Korea Highway Bridge Design Code(Limit States Design) has been applied since 2015. This paper presents the design practice of the crack control specifications, which plays a key role in the critical condition verification and durability evaluation, which are important factors, along with the ultimate strength limit state aimed at the safety of the reinforced concrete structures. Maximum crack spacing derived from the formulation using the allowable crack width to satisfy the service condition and the direct crack control to calculate the crack width from the multiplication of the difference between the average strain difference of reinforcing steel and concrete derived from the crack spacing and tension stiffening effect considering the bond characteristics. Indirect crack control, defined as the maximum reinforcing steel diameters and spacings, were also reviewed. In addition, this paper compares with the direct calculation of crack width and indirect crack control specification of the 2012 revised KCI structural concrete design code based on the ultimate strength design method, which is different from the limit states design method.
\end{abstract}

Additional key words: Crack control, Crack width, Limit states design, Serviceability, Tension stiffening effect

\section{서 론}

2011년 12월 신뢰도 기반의 한계상태설계법을 도입
한 도로교설계기준(한계상태설계법)(1)이 제정된 후, 새로운 설계기준의 도입 준비를 위한 3년간의 시행 유 예기간을 거치고, 2014년 12월 문구 및 일부 규정들을 
수정 - 보완한 부분 개정판(2)을 기준으로 2015년부터 도로교 설계에 적용되고 있다. 개정된 도로교설계기준 (한계상태설계법)은 신뢰도 기반의 한계상태 설계기준 의 적용을 의무화하고 있는 국제사회의 흐름에 부합할 수 있도록, 기존 허용응력설계법 및 강도설계법에 기반 한 설계기준의 부분적 개정이 아닌 국제표준에 부합하 는 신뢰도 기반의 한계상태설계법을 전면적으로 도입 하였다.

3년간의 시행 유예기간을 통하여 콘크리트구조 설 계기술자들과 콘크리트공학을 전공하는 학생들이 도로 교설계기준(한계상태설계법)의 새로운 설계 철학과 이 론을 이해하고, 설계 실무에 적용할 수 있도록 체계적 인 준비를 하고 있을 것으로 판단된다. 그러나 설계 실 무에 직접적으로 도움을 줄 수 있는 해설서 또는 예제 집 등이 부족한 관계로, 도로교설계기준(한계상태설계 법)을 설계 실무에 효율적으로 적용하는데 어려움이 있 을 것으로 사료된다.

이 논문은 지역시스템공학 및 조경공학 분야에서 콘 크리트 구조를 전공으로 하는 설계기술자들과 학생들이 콘크리트구조 한계상태 설계에 대한 내용을 이해하고, 설계 실무에 적용하는데 도움이 될 수 있도록 제 5 장 콘 크리트교 편의 5.6절 사용한계상태 검증에 대한 내용을 주로 다루었다. 그 중 첫 번째에 해당하는 본고에서는 균열제어에 대한 기준의 배경을 소개하고, 관련 예제를 제공하는데 목적이 있다. 이와 함께 콘크리트 구조설계 를 위한 또 다른 국내기준인 2012년 개정 콘크리트구 조기준(3)의 균열제어에 대한 규정과 비교하였다.

\section{균열제어에 관한 이론적 배경}

\section{1. 균열제어 설정 배경 및 접근 방법}

콘크리트 구조물 설계 시 균열제어에 대한 검증 기 준을 두는 중요한 이유들은 구조물의 외관에 대한 심미 적 안정성, 유체의 차폐를 위한 수밀성, 철근의 부식 방 지를 위한 내구성 및 콘크리트 재료의 불확실성 등에 있다. 그러나, 균열과 철근 부식 또는 심미적 안정성 관 점에서의 원인에 대한 명확한 자료들이 상대적으로 부 족하기 때문에 세계 여러 나라의 설계기준에서는 강도 안전성에 비하여 비교적 간략한 규정들로서 기준을 제 시하고 있다.

균열제어와 관련하여 공통적으로 반영하는 요인들 은 부식환경에 따른 허용균열폭, 균열폭에 영향을 주는
철근응력 수준, 철근의 지름, 철근의 간격 및 피복두께 등이 있다. 이들 변수들에 대해서 미국 ACI 318(4)에서 는 실험자료의 통계분석에 근거한 경험적 모델을 기반으 로 하고, 유럽의 CEB-FIP Model Code 1990(MC 90)(5), EUROCODE 2(EC 2)(6) 및 Fib Model Code 2010(MC 2010)(7)에서는 철근과 콘크리트의 개별 재료단위 특 성 및 부착에 의한 합성거동 특성을 바탕으로 역학적 이론에 근거한 모델을 기반으로 한다.

도로교설계기준(한계상태설계법)에서는 국내 실정 에 맞도록 철근과 콘크리트의 개별 재료단위 특성을 규 정한 후 역학적 이론에 근거한 균열제어 모델을 규정하 고 있는데, 균열폭을 직접 계산하여 허용균열폭 또는 한계균열폭의 초과 여부를 검증하는 직접균열제어와 철근의 인장응력 수준에 따라 직접적인 균열폭 계산 없 이 한계균열폭 이내에 있다고 간주할 수 있는 최대철근 지름과 최대철근간격을 제시하는 간접균열제어 등 두 가지 기준으로 규정하고 있다. 2012년 개정 콘크리트 구조기준에서도 도로교설계기준(한계상태설계법)과 유 사한 균열제어 기준을 규정하고 있는데, 기준의 본문에 서는 최대철근간격으로 부록에서는 균열폭 계산식으로 검증하도록 제시하고 있다

\section{2. 기반이론}

철근콘크리트 부재의 균열폭은 Fig. 1(a)에 보인 것 과 같은 철근콘크리트 인장 요소의 주균열(primary crack)면으로부터 양쪽 균열간격내에서의 응력과 변형 률 분포로부터 설명된다. 균열면을 제외한 균열간격 구 간에서는 부착에 의해 콘크리트가 철근의 인장력 일부 를 분담함으로써, 균열간격 내에서 철근과 콘크리트의 변형률의 차이가 발생하게 되고, 이 상대적 차이에 대 한 누적 합이 균열폭 $w$ 가 된다.

이를 다르게 정의한 Lee and $\operatorname{Kim}(8)$ 의 연구에 따르 면 철근과 콘크리트의 강성 및 변형률 차이에 의해 두 재료의 변형량 $\Delta l_{s}, \Delta l_{c}$ 에도 차이가 발생하게 되는데, 이 차이가 미끄럼(slip) $s$ 로 정의되며, 균열면을 중심으 로 양쪽에서 대칭으로 발생하므로 균열폭은 이 미끄럼 양의 두 배가 된다. 이상의 균열폭에 대한 정의를 수식 으로 표현하면 다음과 같다.

$$
w=\int_{s_{r}}\left(\epsilon_{s x}-\epsilon_{c x}\right) d x=\Delta l_{s}-\Delta l_{c}=2 s
$$


(a)

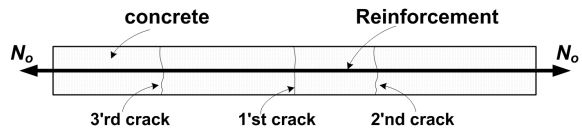

(b)

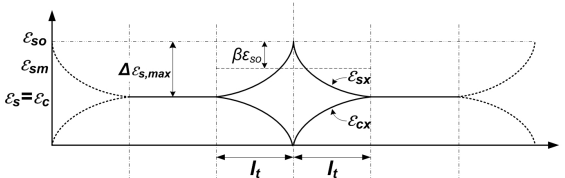

(c)

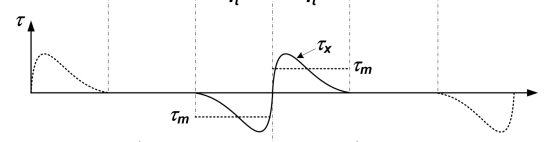

(d)

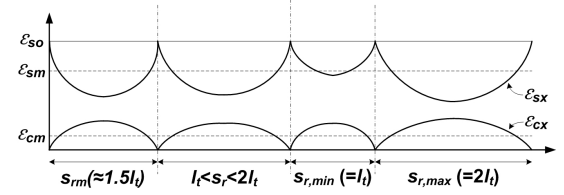

Fig. 1. Distribution of stress and strain in tension members (a) tension members (b) crack formation stage (c) bond stress at crack formation stage (d) stabilized crack stage.

그런데, 이 식을 직접적으로 풀이하기 위해서는 균 열면으로부터 철근 매입길이 방향으로 발생하는 미끄 럼에 대한 정의가 필요한데, 균열안정화단계(stabilized cracking stage)에서의 미끄럼 분포에 대한 수식 유도의 어려움 때문에 간편한 계산을 위하여 평균변형률을 이 용한다. 따라서 균열폭 $w$ 는 균열간격 $s_{r}$ 내에서 철근 과 콘크리트의 평균변형량의 차이로서 다음과 같은 기 본식을 갖는다.

$$
w=\left(\epsilon_{s m}-\epsilon_{c m}\right) s_{r}
$$

철근과 콘크리트의 평균변형률 차이 $\epsilon_{s m}-\epsilon_{c m}$ 은 인 장강화효과(tension stiffening effect)를 반영하여 다음 과 같이 나타낼 수 있다.

$$
\epsilon_{s m}-\epsilon_{c m}=\epsilon_{s o}-\epsilon_{c m}\left(\frac{1+n \rho}{n \rho}\right)
$$

여기서, $\epsilon_{s o}$ 는 균열면에서의 철근 응력, $n$ 은 탄성계 수 비 $\left(E_{s} / E_{c}\right)$ 이며, $\rho$ 는 인장 철근비이다.

콘크리트의 평균변형률 $\epsilon_{c m}$ 은 다음과 같이 콘크리 트의 평균인장응력 $f_{c t m}$ 으로 나타낼 수 있다.

$$
\epsilon_{c m}=\frac{f_{c t m}}{E_{c}}=\frac{n f_{c t m}}{E_{s}}
$$

Eq. (4)와 $\epsilon_{s o}=f_{s o} / E_{s}$ 의 관계로부터 Eq. (3)의 철근 과 콘크리트의 평균변형률 차이를 얻을 수 있다.

$$
\epsilon_{s m}-\epsilon_{c m}=\frac{f_{s o}}{E_{s}}-\frac{(1+n \rho) f_{c t m}}{E_{s} \rho}
$$

균열안정화단계에서 균열간격은 Fig. 1(b)에 나타 낸 것처럼 균열면으로부터 부착이 전달되는 전달길이 (transfer length) $l_{t}$ 에 따라서 최소균열간격은 $l_{t}$, 최대 균열간격은 $2 l_{t}$ 가 된다. 즉, 전달길이에 따른 부착응력 의 평균값을 $\tau_{m}$ 이라고 한다면 철근 표면에서 형성되 는 부착력의 합 $\left(=\tau_{m} \pi d_{b} l_{t}\right)$ 이 콘크리트의 인장강도(= $\left.A_{c} f_{c t m}\right)$ 에 도달할 때 균열이 발생한다고 할 수 있으므로 힘의 평형조건으로부터 다음과 같이 정의할 수 있다.

$$
\tau_{m} \pi d_{b} l_{t}=A_{c} f_{c t m}
$$

이 식에 철근비 $\rho=A_{s} / A_{c}=\pi d_{b}^{2} / 4 A_{c}$ 를 도입하 면, 전달길이 $l_{t}$ 는 다음과 같다.

$$
l_{t}=\frac{d_{b} f_{c t m}}{4 \tau_{m} \rho}
$$

$l_{t}$ 와 $2 l_{t}$ 의 사이값으로 정의되는 균열간격 조건과 $\tau_{m}, f_{c t m}$ 을 포함하는 포괄적인 실험상수 $k_{1}$ 를 도입하 면 균열간격 $s_{r}$ 은 다음과 같다.

$$
s_{r}=k_{1} \frac{d_{b}}{\rho}
$$

그런데, Eq. (8a)는 콘크리트 단면에 인장응력이 등 분포한다는 가정으로부터 유도되었지만 실제는 철근 주변의 응력이 부재의 표면보다 큰 값을 나타낸다. 따 라서 균열간격에 영향을 미치는 또다른 변수로 콘크리 트의 순피복두께 $c_{c}$ 를 반영하여 다음과 같이 표현할 수 도 있다.

$$
s_{r}=k c_{c}+k_{1} \frac{d_{b}}{\rho}
$$




\section{한계상태설계법의 균열 제어}

\section{1. 직접균열제어(균열폭 계산)}

Fig. 2 에 보인 것과 같이 휨을 받는 부재의 인장영역 에 발생하는 균열은 앞 절에서 설명한 인장요소의 균열 거동과 동일하다. 따라서 직접인장 요소의 균열폭을 결 정하는 균열간격, 철근과 콘크리트의 평균변형률의 차 이를 그대로 사용하여 휨부재의 균열폭을 산정할 수 있 다. 다만, 단면 깊이에 따라 인장응력의 크기가 변하는 휨부재의 특성을 반영하기 위하여 인장영역을 등가의 직접인장부재 즉, 인장 현재(tension chord)로 변환할 필요가 있다. 도로교설계기준(한계상태설계법)에서는 Fig. 2에 음영으로 나타낸 유효인장면적 $A_{c t e}$ 를 사용하 여 직접인장부재처럼, 즉 부재 형태에 따라 인장 현재 로 간주할 수 있는 깊이 $d_{c t e}$ 를 다음과 같이 규정하고 있다.

$$
\begin{array}{ll}
\text { 보(beam) } & d_{c t e}=2.5(h-d) \\
\text { 슬래브(slab) } & d_{c t e}=2.5 t_{c} \leq \frac{h-c}{3} \\
\text { 벽체(tension member) } & d_{c t e}=2.5 t_{c} \leq 0.5 t
\end{array}
$$

여기서 $t_{c}$ 는 인장연단에서 철근 중심까지의 피복두 께이고, $t$ 는 벽체 두께이다.

Eq. (9)로 정의된 인장 현재의 깊이를 이용하여 유효 인장면적을 결정하고, 다음과 같은 등가의 유효 인장철 근비 $\rho_{e}$ 를 이용하도록 규정하고 있다.

$$
\rho_{e}=\frac{A_{s}}{A_{c t e}}=\frac{A_{s}}{b d_{c t e}}
$$

도로교설계기준(한계상태설계법)에서는 균열폭에
대한 이론식인 Eq. (1)을 기반으로 하여 균열 발생 후의 모든 하중 단계에서 검증할 수 있는 설계 균열폭 $w_{k}$ 를 다음 식으로 규정하고 있다.

$$
w_{k}=l_{r, \max }\left(\epsilon_{s m}-\epsilon_{c m}\right)
$$

여기서, $l_{r, \max }$ 는 최종 균열의 최대 간격으로, 2012 년 개정 도로교설계기준(한계상태설계법)에서는 균열 간격 기준식 (8)에 대해서 실험상수 $k_{1}$ 을 $1 / 3.6$ 으로 결 정하고, 유효인장철근비 $\rho_{e}$ 를 도입하여 다음 식으로 계 산한다.

$$
l_{r, \text { max }}=\frac{d_{b}}{3.6 \rho_{e}} \leq \frac{f_{s} d_{b}}{3.6 f_{c t}}
$$

이와는 다르게 2014년 부분 개정된 도로교설계기준 (한계상태설계법)에서는 균열간격에 영향을 주는 중요 변수인 피복두께의 영향과 철근 표면 형태에 따른 부착 특성과 하중특성을 포괄적으로 고려할 수 있도록 기존 실험결과의 통계적 특성값을 바탕으로 $l_{r, \max }$ 을 다음 식으로 규정하고 있다.

$$
l_{r, \max }=3.4 c_{c}+0.425 k_{1} k_{2} \frac{d_{b}}{\rho_{e}}
$$

여기서 $c_{c}$ 는 최외단 인장철근 또는 긴장재 표면과 콘크리트 표면 사이의 최소 피복두께 $(\mathrm{mm}), k_{1}$ 은 철근 표면 형태에 따른 부착계수로서 이형철근은 0.8 , 원형 철근은 1.6 이고, $k_{2}$ 는 하중계수로 휨이면 0.5 , 직접인장 이면 1.0 이다.

$\epsilon_{s m}-\epsilon_{c m}$ 은 철근과 콘크리트의 평균 변형률 차이로 서, 앞 절에서 정의한 Eq. (5)에 대해서 유효철근비 $\rho_{e}$

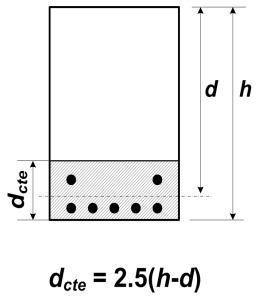

(a) Beam

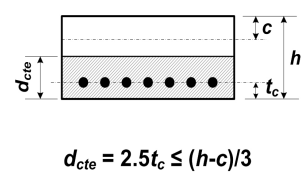

(b) Slab

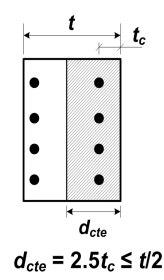

(c) Member in tension

Fig. 2. Effective tension areas in reinforced concrete flexural members. 
로 치환하고, 인장강화효과에 대한 실험상수 $\beta_{t}$ 를 0.4 로 도입하여 다음 식으로 계산한다.

$$
\epsilon_{s m}-\epsilon_{c m}=\left[\frac{f_{s o}}{E_{s}}-0.4 \frac{\left(1+n \rho_{e}\right) f_{c t}}{E_{s} \rho_{e}}\right] \geq 0.6 \frac{f_{s o}}{E_{s}}
$$

Eq. (12), Eq. (13)으로 정의되는 최대균열간격과 평 균변형률의 차이를 Eq. (11)에 대입하여 최대균열폭에 해당하는 설계균열폭을 계산한다. 그리고, 계산된 설계 균열폭 $w_{k}$ 가 한계 균열폭을 초과하지 않는지 검토하는 것으로서 사용한계상태 검증을 실시한다. 도로교설계 기준(한계상태설계법)에서 규정하는 설계 등급에 따른 한계 균열폭은 Table 1과 같다.

2012년 개정 콘크리트구조기준에서도 도로교설계 기준(한계상태설계법)과 동일한 기반이론으로 설계 균 열폭 $w_{d}$ 를 다음 식과 같이 규정하고 있다. 다만, 최대 균열폭만을 정의하는 도로교설계기준(한계상태설계 법)과 다르게 평균 균열폭을 기준식으로 하면서 최대 균열폭까지도 고려할 수 있도록 균열폭 평가계수 $k_{s t}$ 가 추가되는 차이가 있다.

$$
w_{d}=k_{s t} \cdot w_{m}=k_{s t} \cdot l_{s}\left(\epsilon_{s m}-\epsilon_{c m}\right)
$$

여기서, $k_{s t}$ 는 발주자(또는 건축주)가 해당 철근콘크 리트 구조물의 특성을 고려하여 결정할 수 있는 균열폭 평가계수로서, 평균균열폭을 계산할 때에는 1.0 , 최대 균열폭을 계산할 때에는 1.7 을 적용한다.

$l_{s}$ 는 평균 균열간격으로서 부착된 철근의 중심 간격
이 $5\left(c_{c}+d_{b} / 2\right)$ 이하인 경우는 Eq. (8)의 기본식에 피복 두께 $c_{c}$ 의 영향을 고려한 다음 Eq. (15a)로 계산하고, 부착된 철근의 중심 간격이 $5\left(c_{c}+d_{b} / 2\right)$ 을 초과하는 경우에는 Eq. (15b)로 계산한다.

$$
\begin{gathered}
l_{s}=2 c_{c}+\frac{0.25 k_{1} \cdot k_{2} \cdot d_{b}}{\rho_{e}} \\
l_{s}=0.75(h-x)
\end{gathered}
$$

여기서, $c_{c}$ 는 최외단 인장철근이나 긴장재의 표면과 콘크리트 표면 사이의 최소 피복두께이고, $k_{1}$ 은 부착강 도에 따른 계수로서 이형철근은 0.8 , 원형철근이나 긴 장재는 1.6 을 적용한다. $k_{2}$ 는 하중작용에 따른 계수로 서 휨모멘트를 받는 부재는 0.5 , 직접인장력을 받는 부 재는 1.0 을 적용하며, 편심을 가진 직접인장력을 받는 부재나 부재의 국부적인 부분의 균열폭을 계산할 때에 는 다음 식을 적용한다.

$$
k_{2}=\frac{\epsilon_{1}+\epsilon_{2}}{2 \epsilon_{1}}
$$

여기서, $\epsilon_{1}$ 과 $\epsilon_{2}$ 는 단면 표면의 인장변형률로서 둘 중의 큰 값을 $\epsilon_{1}$ 으로 한다.

철근과 콘크리트의 평균변형률 차이는 도로교설계 기준(한계상태설계법)과 유사하게 인장강화효과를 반

\begin{tabular}{|c|c|c|c|}
\hline \multirow{2}{*}{$\begin{array}{l}\text { 설계 } \\
\text { 등급 }\end{array}$} & \multicolumn{2}{|c|}{ 사용한계상태 하중조합 } & \multirow{2}{*}{ 표면 한계균열폭 (mm) } \\
\hline & 영(0)응력 한계상태 & 균열폭 한계상태 & \\
\hline $\mathrm{A}$ & 사용하중조합- I & - & - \\
\hline $\mathrm{B}$ & 사용하중조합-III/IV & 사용하중조합- I & 0.2 \\
\hline $\mathrm{C}$ & $\begin{array}{c}\text { 지속하중조합(2012) } \\
\text { 사용하중조합-V(2014) }\end{array}$ & 사용하중조합-III/IV & 0.2 \\
\hline $\mathrm{D}$ & & 사용하중조합-III/IV & 0.3 \\
\hline $\mathrm{E}$ & & $\begin{array}{c}\text { 지속하중조합(2012) } \\
\text { 사용하중조합-V(2014) }\end{array}$ & 0.3 \\
\hline
\end{tabular}
영하여 계산한다. 다만, $\mathrm{MC} 90$ 에 정의된 1 차식 형태의 인장강화효과를 적용하고 있는 도로교설계기준(한계 상태설계법)과 다르게 2012년 개정 콘크리트구조기준

Table 1. Recommended values of crack width 
에서는 EC 2에 정의된 2차식 형태의 인장강화효과를 적용하여 다음 식과 같이 계산한다.

$$
\epsilon_{s m}-\epsilon_{c m}=\frac{f_{s o}}{E_{s}}\left[1-\beta_{1} \beta_{2}\left(1+n_{i} \rho_{e}\right)\left(\frac{f_{s r}}{f_{s o}}\right)^{2}\right] \geq 0.6 \frac{f_{s o}}{E_{s}}
$$

여기서, $f_{s o}$ 는 균열단면의 철근응력, $f_{s r}$ 은 균열이 발생한 직후 균열면에서 계산한 철근응력이다. $\beta_{1}$ 은 부착특성에 따른 계수로서 이형철근이면 1.0 , 원형철근 이나 강연선은 0.5 이다. $\beta_{2}$ 는 하중조건에 따른 계수로 서 반복하중일 경우 0.5, 그 외의 경우에는 1.0 이다. $n_{i}$ 는 콘크리트의 초기접선탄성계수에 대한 철근의 탄성 계수비이다.

\section{2. 간접균열제어(최대철근간격 및 철근지름)}

앞 절에서 설명한 바와 같이 균열폭을 직접 계산하 고 한계값과 비교하여 사용한계상태를 검증하는 과정 은 상당히 복잡한 계산 과정을 거쳐야 하는 어려움이 있다. 그런데, 실제 설계에서 한계 균열폭 이내에 있다 고 간주할 수 있는 일정 기준(최대철근지름 또는 최대 철근간격)을 만족한다면 균열폭 계산을 통한 검증 과정 을 피할 수 있게 된다. 즉, 최소철근량 조건을 만족하고, 배치된 철근이 최대 지름과 최대 간격 중의 하나를 만 족한다면 균열폭이 허용 한계값 이내에 있다고 간주할 수 있다.

이를 위하여 도로교설계기준(한계상태설계법)에서 는 앞 절의 균열폭 계산식을 철근 지름과 철근 간격에 대한 식으로 변환한 후, 한계 균열폭 $0.3 \mathrm{~mm}$ 를 만족하 도록 Fig. 3과 같은 방법에 의해 철근의 각 응력 수준에 서 필요한 최대 지름과 최대 간격으로 각각 규정하고 있다.

이상과 같은 방법을 통하여 계산된 최대철근지름과 최대철근간격은 Table 2 와 같다. $\operatorname{Kim}(9)$ 의 연구에 따 르면 이 표의 자료는 사각형 단면 부재를 바탕으로 콘 크리트 인장강도 $f_{c t}$ 가 $2.5 \mathrm{~N} / \mathrm{mm}^{2}\left(f_{c k}=27 \mathrm{~N} / \mathrm{mm}^{2}\right.$ 에 해당)이고, 피복두께를 $0.1 h(=h-d)$ 로 고정한 후 미 리 정한 철근 응력 수준마다 단면의 높이를 변화시켜가 면서 한계균열폭에 해당하는 철근의 지름과 간격을 계 산하여 최대값들을 정리한 것이다.

2012년 개정 콘크리트구조기준에서는 간접균열제 어에 대해서 콘크리트 인장연단에 가장 가까이에 배치
되는 철근의 중심 간격 $s$ 가 다음 두 식에 의해 계산된 값 중에서 작은 값 이하로 되도록 규정하고 있다. 다만, 부록 III의 규정에 따라 균열폭을 직접 계산하는 경우에 는 이 규정을 따르지 않을 수 있다.

$$
\begin{aligned}
& s=375\left(\frac{k_{c r}}{f_{s}}\right)-2.5 c_{c} \\
& s=300\left(\frac{k_{c r}}{f_{s}}\right)
\end{aligned}
$$

여기서, $k_{c r}$ 은 부록 III에 정의된 건조환경에 노출되 는 경우에는 280 , 그 외의 환경에 노출되는 경우에는 210 이다. $c_{c}$ 는 인장철근의 표면과 콘크리트 표면 사이 의 최소 두께이다. $f_{s}$ 는 사용하중 상태에서 인장연단에 가장 가까이에 위치한 철근의 응력으로서, 간단한 방법 으로 균열을 검증하고자 할 때는 $f_{s}$ 를 $f_{y}$ 의 $2 / 3$ 을 근사 적으로 사용할 수 있다.

\section{균열제어 예제}

철근콘크리트 구조물의 사용한계상태 기반 균열제 어에 대한 이해를 높이기 위하여 균열폭을 계산하여 허 용균열폭 초과 여부를 검토하는 직접균열제어와 최대 철근간격 또는 최대철근직경에 의한 간접균열제어에 대해서 예제를 통하여 검토를 수행하였다. 예제의 풀이 에 있어서 각 설계법별로 도로교설계기준(한계상태설 계법) 해설(10) 및 콘크리트구조기준 예제집(11)을 참 고하였다.

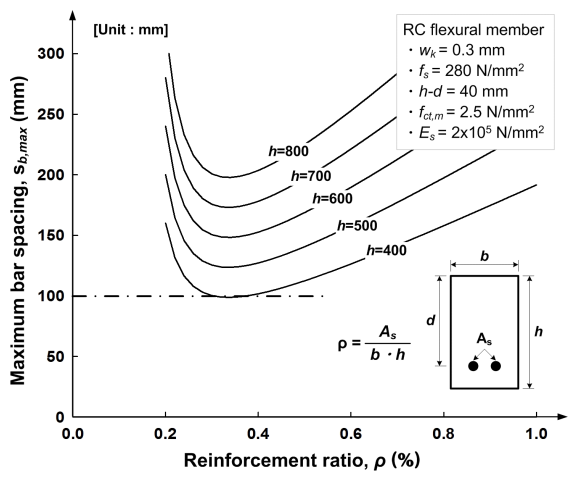

Fig. 3. Calculation of maximum reinforcing bar spacing in reinforced concrete flexural members. 
Table 2. Maximum reinforcing bar diameters and spacings for structural concrete members

\begin{tabular}{|c|c|c|c|c|c|}
\hline \multirow{2}{*}{$\begin{array}{c}\text { 철근 } \\
\text { 응력 } \\
\left(\mathrm{N} / \mathrm{mm}^{2}\right)\end{array}$} & \multicolumn{2}{|c|}{ 최대 철근 지름 (mm) } & \multicolumn{3}{|c|}{ 최대 철근 간격 (mm) } \\
\hline & $\begin{array}{c}\text { 철근 } \\
\text { 콘크리트 }\end{array}$ & $\begin{array}{c}\text { 프리스트레스트 } \\
\text { 콘크리트 }\end{array}$ & $\begin{array}{l}\text { 철근콘크리트 } \\
\text { 순수휨단면 }\end{array}$ & $\begin{array}{l}\text { 철근콘크리트 } \\
\text { 순수인장단면 }\end{array}$ & $\begin{array}{l}\text { 프리스트레스트 } \\
\text { 콘크리트 단면 }\end{array}$ \\
\hline 160 & 32 & 25 & 300 & 200 & 200 \\
\hline 200 & 25 & 16 & 250 & 150 & 150 \\
\hline 240 & 16 & $12^{*} / 13^{* *}$ & 200 & 125 & 100 \\
\hline 280 & $12^{*} / 14^{* *}$ & 8 & 150 & 75 & 50 \\
\hline 320 & 10 & 6 & 100 & - & - \\
\hline 360 & 8 & 5 & 50 & - & - \\
\hline
\end{tabular}

*2012년 개정 도로교설계기준(한계상태설계법).

** 2014년 부분개정 도로교설계기준(한계상태설계법).

균열제어 검토 대상은 교량 바닥판 슬래브로서 표준 하중조합에 의해 경간 중앙에 $85 \mathrm{kN} \cdot \mathrm{m} / \mathrm{m}$ 의 휨모멘 트가 발생하는 것으로 하였다. 이 휨모멘트의 $15 \%$ 는 자중을 포함한 고정하중에 의한 것이고, 나머지 $85 \%$ 가 통행 트럭하중인 활하중에 의해 유발된 것이다. 극한한 계상태 설계를 통하여 깊이가 $250 \mathrm{~mm}$, 유효깊이 $192 \mathrm{~mm}$ 이며, $\mathrm{D} 16$ 철근이 $100 \mathrm{~mm}$ 간격 $\left(A_{s}=1,986 \mathrm{~mm}^{2} / \mathrm{m}\right)$ 으로 배치되었다. 슬래브에 사용된 재료는 콘크리트의 경우 기준압축강도 $f_{c k}=30 \mathrm{~N} / \mathrm{mm}^{2}$, 철근의 경우 기준 항복강도 $f_{y}=400 \mathrm{~N} / \mathrm{mm}^{2}$ 이며, 대상 교량은 습도가 높은 임해 지역에 시공되며, 타설 2주 후에 거푸집을 제거할 예정이다.

\section{1. 도로교설계기준(한계상태설계법)에 따른 균열폭 계산}

Step 1) 적용설계등급

지속하중조합이므로 한계균열폭 $0.3 \mathrm{~mm}$ 인 E등급

\section{Step 2) 재료 및 단면특성}

(1) 재료강도

$$
\begin{aligned}
& f_{c k}=30 \mathrm{~N} / \mathrm{mm}^{2}, f_{y}=400 \mathrm{~N} / \mathrm{mm}^{2} \\
& f_{c m}=f_{c k}+\Delta f=30+4=34 \mathrm{~N} / \mathrm{mm}^{2} \\
& \qquad \quad\left(f_{c k} \leq 40 \mathrm{~N} / \mathrm{mm}^{2}\right) \\
& f_{c t m}=0.3 \times f_{c m}^{\frac{2}{3}}=0.3 \times(30+4)^{\frac{2}{3}}=3.15 \mathrm{~N} / \mathrm{mm}^{2} \\
& E_{s}=2 \times 10^{5} \mathrm{~N} / \mathrm{mm}^{2},
\end{aligned}
$$

$$
\begin{aligned}
& E_{c}=8,500 \sqrt[3]{f_{c m}}=8,500 \sqrt[3]{34}=27,500 \mathrm{~N} / \mathrm{mm}^{2} \\
& n=E_{s} / E_{s}=7.3
\end{aligned}
$$

$$
\begin{aligned}
& \text { (2) 사용철근량 } \\
& A_{s}=\mathrm{D} 16 @ 100 \mathrm{~mm}=1,986 \mathrm{~mm}^{2} \\
& \rho=A_{s} / b d=1,986 /(1,000 \times 192)=0.0103
\end{aligned}
$$

(3) 단면특성

$b=1,000 \mathrm{~mm}, h=250 \mathrm{~mm}, d=192 \mathrm{~mm}$

비균열 단면2차모멘트

$$
I_{g}=\frac{b h^{3}}{12}=\frac{1,000 \times 250^{3}}{12}=1,302 \times 10^{6} \mathrm{~mm}^{4} / \mathrm{m}
$$

Step 3) 사용기간 중 표준하중조합(사용하중조합-I) 에서 균열 발생 여부 검토

지속하중에 의한 모멘트

$M_{\text {sus }}=85 \times 10^{6} \mathrm{~N} \cdot \mathrm{mm}$

슬래브 인장 연단의 응력

$f_{b}=\frac{M}{I_{g}} y=\frac{85 \times 10^{6} \times 125}{1,302 \times 10^{6}}=8.16 \mathrm{~N} / \mathrm{mm}^{2}$

$f_{b}>f_{c t m}\left(=3.15 \mathrm{~N} / \mathrm{mm}^{2}\right)$ 이므로 단면에는 균열이

발생

Step 4) 응력 검토

(1) 크리프가 발생하지 않는 상태 
중립축 깊이비 $k$

$$
\begin{aligned}
k & =\sqrt{(n \rho)^{2}+2 n \rho}-n \rho \\
& =\sqrt{(7.3 \times 0.0103)^{2}+2(7.3)(0.0103)}-7.3(0.0103) \\
& =0.316
\end{aligned}
$$

압축 연단 콘크리트 응력

$$
\begin{aligned}
f_{c} & =\frac{2 M}{\left(1-\frac{k}{3}\right) b c d}=\frac{2 \times 85 \times 10^{6}}{0.895(1000)(60.7)(192)} \\
& =16.3 \mathrm{~N} / \mathrm{mm}^{2}
\end{aligned}
$$

철근 응력

$$
\begin{aligned}
f_{s} & =\frac{M}{A_{s}\left(1-\frac{k}{3}\right) d}=\frac{85 \times 10^{6}}{1,986(0.895)(192)} \\
& =249 \mathrm{~N} / \mathrm{mm}^{2}
\end{aligned}
$$

(2) 지속하중에 의해 모든 크리프가 발생한 상태 콘크리트의 최종 크리프 계수 $\psi(\infty, 14)=2.2$; 습 도가 높은 임해 지역 시공 및 2주후 거푸집 제거

콘크리트의 유효 탄성계수

$$
\begin{aligned}
E_{c e} & =\frac{\left(M_{d}+M_{l}\right) E_{c}}{M_{l}+(1+\psi) M_{d}}=\frac{(0.15+0.85)(27,500)}{0.85+(1+2.2)(0.15)} \\
& =20,680 \mathrm{~N} / \mathrm{mm}^{2}
\end{aligned}
$$

유효탄성계수비 $n_{e}=E_{s} / E_{c e}=9.7$

중립축 깊이비 $k=0.354$ 가 되어 중립축 깊이 $c=$ $68 \mathrm{~mm}$

압축 연단 콘크리트 응력

$f_{c}=\frac{2 \times 85 \times 10^{6}}{0.882(1000)(68)(192)}=14.8 \mathrm{~N} / \mathrm{mm}^{2}$

\section{철근 응력}

$f_{s}=\frac{85 \times 10^{6}}{1,986(0.882)(192)}=253 \mathrm{~N} / \mathrm{mm}^{2}$

Step 5) 유효인장철근비 및 설계 최대균열간격

$$
\begin{aligned}
& d_{c t e}=\min \left\{\begin{array}{l}
2.5(h-d)=2.5(250-192)=145 \\
(h-c) / 3=(250-68) / 3=62.2
\end{array}\right. \\
& d_{c t e}=62.2 \mathrm{~mm}
\end{aligned}
$$

$$
\begin{aligned}
& \rho_{e}=\frac{A_{s}}{A_{c t e}}=\frac{A_{s}}{d_{c t e} \times b}=\frac{1,986}{62.2 \times 1,000}=0.0319 \\
& l_{r, \text { max }}=\frac{d_{b}}{3.6 \rho_{e}}=\frac{15.9}{3.6 \times 0.0319}=138 \mathrm{~mm}
\end{aligned}
$$

; 2012년 도로교설계기준

$$
\begin{aligned}
l_{r, \mathrm{max}} & =3.4 c_{c}+0.425 k_{1} k_{2} \frac{d_{b}}{\rho_{e}} \\
& =3.4 \times 50+0.425(0.8)(0.5) \times \frac{15.9}{0.0319} \\
& =254.8 \mathrm{~mm}
\end{aligned}
$$

; 2014년 도로교설계기준-부분개정

Step 6) 철근과 콘크리트의 평균변형률

유효탄성계수비 $n_{e}=E_{s} / E_{c e}=9.7$ 와 철근응력 $f_{\text {so }}=253 \mathrm{~N} / \mathrm{mm}^{2}$ 을 적용

$$
\begin{aligned}
\epsilon_{s m}-\epsilon_{c m} & =\frac{f_{s o}}{E_{s}}-\frac{0.4 f_{c t}\left(1+n \rho_{e}\right)}{E_{s} \rho_{e}} \\
& =\frac{253}{200,000}-\frac{0.4(3.15)(1+9.7 \times 0.0319)}{200,000 \times 0.0319} \\
& =0.00152
\end{aligned}
$$

Step 7) 설계균열폭

$$
\begin{aligned}
& w_{k}=l_{r, \text { max }}\left(\epsilon_{s m}-\epsilon_{c m}\right)=138 \times 0.00152 \\
&= 0.21 \mathrm{~mm} \quad ; 2012 \text { 년 도로교설계기준 } \\
& w_{k}=l_{r, \text { max }}\left(\epsilon_{s m}-\epsilon_{c m}\right)=255 \times 0.00152 \\
&=0.388 \mathrm{~mm}
\end{aligned}
$$

; 2014년 도로교설계기준-부분개정

예제의 바닥 슬래브에서 예상되는 균열폭은 2012년 도로교설계기준(한계상태설계법)의 균열간격을 이용 하면 $0.21 \mathrm{~mm}$ 로서 도로교설계기준(한계상태설계법)의 한계균열폭의 지속하중조합에 해당하는 $0.3 \mathrm{~mm}$ 보다 작으므로 규정에 적합하다. 그러나, 2014년 도로교설계 기준(한계상태설계법) 부분개정의 균열간격을 이용하 면 $0.388 \mathrm{~mm}$ 로서 한계균열폭을 초과하지만 이 값은 지속하중조합보다 큰 표준하중조합에 의해 계산된 균 열폭으로서 지속하중의 크기가 표준하중의 $15 \%$ 에 해 당하기 때문에 적합하다고 할 수 있다.

\section{2012년 개정 콘크리트구조기준에 따른 균열폭 계산}


Step 1) 재료 상수 및 철근 단면적

$E_{s}=200,000 \mathrm{~N} / \mathrm{mm}^{2}$

$f_{c u}=f_{c k}+\Delta f=30+4=34 \mathrm{~N} / \mathrm{mm}^{2}$

$E_{c}=8,500 \sqrt[3]{f_{c u}}=8,500 \sqrt[3]{34}=27,537 \mathrm{~N} / \mathrm{mm}^{2}$

$E_{c i}=1.18 E_{c}=32,494 \mathrm{~N} / \mathrm{mm}^{2}$

$n=\frac{E_{s}}{E_{c}}=\frac{200,000}{27,537}=7.3$,

$n_{i}=\frac{E_{s}}{E_{c i}}=\frac{200,000}{32,494}=6.2$

$f_{r}=0.63 \lambda \sqrt{f_{c k}}=0.63 \times 1.0 \times \sqrt{30}=3.45 \mathrm{~N} / \mathrm{mm}^{2}$

$A_{s}(10-\mathrm{D} 16)=1,986 \mathrm{~mm}^{2}, d_{b}=15.9 \mathrm{~mm}$

Step 2) 단면2차모멘트

(1) 전단면2차모멘트

철근의 환산단면적

$n_{i} A_{s}=6.2 \times 1,986=12,313.2 \mathrm{~mm}^{2}$

비균열 환산단면에 대한 해석으로 단면 상단으로부 터의 중립축 거리 $y_{0}=125 \mathrm{~mm}$

전단면2차모멘트 $I_{g}=1,302 \times 10^{6} \mathrm{~mm}^{4}$

(2) 균열단면2차모멘트

균열 환산단면에 대한 해석으로 단면 상단으로부터 의 중립축 거리 $y_{0}=57.6 \mathrm{~mm}$

균열단면2차모멘트 $I_{c r}=286 \times 10^{6} \mathrm{~mm}^{4}$

Step 3) 균열모멘트

단면 총 높이 $h_{t}=250 \mathrm{~mm}$

$M_{c r}=\frac{f_{r} I_{g}}{h_{t}-y_{o}}=\frac{3.45\left(1,320 \times 10^{6}\right)}{250-125}=36.43 \mathrm{kN} \cdot \mathrm{m}$

Step 4) 균열발생 여부 판정 및 철근응력

$$
\begin{aligned}
M_{s} & =85 \mathrm{kN} \cdot \mathrm{m}>M_{c r} \\
f_{s o} & =n_{i} \frac{M_{s}}{I_{c r}}\left(d-y_{o}\right)=6.2 \times \frac{85 \times 10^{6}}{286 \times 10^{6}} \times(192-57.6) \\
& =247.7 \mathrm{~N} / \mathrm{mm}^{2}
\end{aligned}
$$

균열이 발생한 직후 균열면에서 계산한 철근응력 $f_{s r}=n_{i} \frac{M_{c r}}{I_{c r}}\left(d-y_{o}\right)$

$$
\begin{aligned}
& =6.2 \times \frac{36.43 \times 10^{6}}{286 \times 10^{6}} \times(192-57.6) \\
& =106.1 \mathrm{~N} / \mathrm{mm}^{2}
\end{aligned}
$$

\section{Step 5) 콘크리트 유효인장면적}

$$
\begin{aligned}
& d_{c t e}=\min \left\{\begin{array}{l}
2.5(h-d)=2.5(250-192)=145 \\
(h-x) / 3=(250-57.6) / 3=64.13
\end{array}\right. \\
& d_{c t e}=64.13 \mathrm{~mm} \\
& A_{c t e}=b \times d_{c t e}=1,000 \times 64.13=64,130 \mathrm{~mm}^{2} \\
& \rho_{e}=\frac{A_{s}}{A_{c t e}}=\frac{1,986}{64,130}=0.031
\end{aligned}
$$

Step 6) 철근의 중심간격 판정 및 평균균열간격 $5\left(c_{c}+d_{b} / 2\right)=5(42.1+15.9 / 2)=250.25 \mathrm{~mm}$ 부착된 철근의 중심간격은 $100 \mathrm{~mm}$ 로서 $250.25 \mathrm{~mm}$ 이하이므로

$$
\begin{aligned}
& l_{s}=2 c_{c}+\frac{0.25 k_{1} k_{2} d_{b}}{\rho_{e}} \\
& =2 \times 42.1+\frac{0.25 \times 0.8 \times 0.5 \times 15.9}{0.031}=135.5 \mathrm{~mm}
\end{aligned}
$$

여기서 $k_{1}$ 은 $0.8, k_{2}$ 는 0.5 를 사용

Step 7) 평균변형률

$$
\begin{aligned}
& \epsilon_{s m}-\epsilon_{c m}=\frac{f_{s o}}{E_{s}}\left[1-\beta_{1} \beta_{2}\left(1+n_{i} \rho_{e}\right)\left(\frac{f_{s r}}{f_{s o}}\right)^{2}\right] \geq 0.6 \frac{f_{s o}}{E_{s}} \\
& =\frac{247.7}{200,000}\left[1-1.0 \times 1.0 \times(1+6.2 \times 0.031)\left(\frac{106.1}{247.7}\right)^{2}\right] \\
& \quad \geq 0.6 \times \frac{247.7}{200,000} \\
& =0.9676 \times 10^{-3} \geq 0.7431 \times 10^{-3} \\
& \text { 여기서 } \beta_{1} \text { 은 } 1.0, \beta_{2} \text { 는 } 1.0 \text { 을 사-ᄋㅛㅇ }
\end{aligned}
$$

Step 8) 설계 균열폭

$$
\begin{aligned}
w_{d} & =k_{s t} w_{m}=k_{s t} l_{s}\left(\epsilon_{s m}-\epsilon_{c m}\right) \\
& =1.7 \times 135.5 \times 0.9676 \times 10^{-3}=0.223 \mathrm{~mm}
\end{aligned}
$$

여기서 $k_{s t}$ 는 최대균열폭을 계산하기 위해 1.7 을 사용

\section{3. 도로교설계기준(한계상태설계법)에 따른 간접균열제어}

Step 1) 최소철근량 검토

간접균열제어는 최소철근량 규정을 만족한 상태에 서만 적용이 가능하며, 이에 따른 콘크리트의 인장영 
역 면적은 균열 발생 직전의 인장 영역이므로 바닥 슬 래브 단면의 절반에 해당하므로, $A_{c t}=1,000 \times \frac{250}{2}=$ $125,000 \mathrm{~mm}^{2}$, 축력이 작용하지 않으므로 $k_{c}=0.4(1-0)$ $=0.4$, 깊이가 $300 \mathrm{~mm}$ 이하인 직사각형 단면이므로 $k=1.0$ 을 적용한다.

최소철근량 결정에 필요한 철근 응력의 크기는 제약 조건이 없다면 항복강도로 취할 수 있다. 그러나, 이 바 닥판 슬래브에서는 간접균열제어 규정에 적합하도록 Table 2에 따라 D16 철근의 응력을 $240 \mathrm{~N} / \mathrm{mm}^{2}$ 로 제한 하거나, 또는 $100 \mathrm{~mm}$ 간격에 부합하는 $320 \mathrm{~N} / \mathrm{mm}^{2}$ 로 정해야 하는데, 이 예제에서는 엄격한 설계를 위해서 $240 \mathrm{~N} / \mathrm{mm}^{2}$ 로 산정한다.

따라서, 소요 최소철근량

$A_{s, \text { min }}=\frac{0.4(1.0)(3.15)(125,000)}{240}=667 \mathrm{~mm}^{2} / \mathrm{m}$ 이 되

고, 예제 단면에 배치된 철근량 $A_{s}=1,986 \mathrm{~mm}^{2} / \mathrm{m}$ 는 최소 철근량 $A_{s, \mathrm{~min}}$ 보다 많기 때문에 적합한 설계라고 할 수 있으며, 간접균열제어 규정의 적용 가능하다.

\section{Step 2) 최대철근지름 및 최대철근간격}

$15 \%$ 에 해당하는 활하중과 $85 \%$ 에 해당하는 고정하 중을 모두 사용하중으로 고려한 상태에 대해서 철근의 응력을 계산한 결과는 $249 \mathrm{~N} / \mathrm{mm}^{2}$ 이므로, 이 응력값을 기준으로 Table 2 의 최대철근지름과 최대철근간격을 검토하면 최대철근지름은 $16 \mathrm{~mm}$ 이하, 최대철근간격 은 철근 응력 상태에 따라서 선형 보간을 하면 $190 \mathrm{~mm}$ 이하를 만족하면 된다.

따라서, 예제의 바닥 슬래브에 사용된 철근은 D16 이며, 철근이 $100 \mathrm{~mm}$ 간격으로 배치된 상태이기 때문 에 최대철근간격 규정을 만족하므로 간접균열제어 규 정에 적합하다.

\section{2012년 개정 콘크리트구조기준에 따른 간접균열제어}

\section{Step 1) 최대철근간격}

최외측 인장철근과 콘크리트 표면사이의 최소 두께 $c_{c}$ 는 $50 \mathrm{~mm}$, 습윤환경에 노출되어 있으므로 $\kappa_{c r}$ 은 210 , 사용하중에 의해 철근에 발생하는 응력 $f_{s}$ 는 $247.7 \mathrm{~N} / \mathrm{mm}^{2}$ 이므로, 간접균열제어를 위한 철근간격 $s$ 는 다음과 같다.

$$
\begin{aligned}
& s=375\left(\frac{210}{247.7}\right)-2.5(50)=192.9 \mathrm{~mm} \\
& s=300\left(\frac{210}{247.7}\right)=254.3 \mathrm{~mm}>192.9 \mathrm{~mm}
\end{aligned}
$$

계산된 값 중에서 작은 값 이하여야 하므로 최대철 근간격은 $192.9 \mathrm{~mm}$ 이며, 콘크리트 인장 연단에서 가장 가까이 배치되는 철근의 중심 간격 $s$ 는 $100 \mathrm{~mm}$ 로서 계산된 값보다 작으므로 적합하다.

\section{결 론}

이 연구에서는 도로교설계기준(한계상태설계법) 콘 크리트교편의 사용한계상태 검증 중 균열제어에 대한 배경 및 기반이론을 소개하고, 관련 예제 풀이 및 2012 년 개정 콘크리트구조기준의 규정과 비교를 하였다. 이 를 통하여 콘크리트 구조물의 설계, 시공 및 관리 업무 에 종사하는 기술자들과 콘크리트 구조를 공부하는 학 생들이 균열제어에 대한 전반적인 내용들을 이해하고 적용하는데 작은 도움이 될 수 있을 것으로 기대된다.

\section{요 약}

신뢰도 기반 설계기준의 적용을 의무화하고 있는 국 제적인 요구에 부합할 수 있도록 콘크리트 구조설계에 한계상태설계법을 전면적으로 도입한 도로교설계기준 (한계상태설계법)이 2015년부터 적용되고 있다. 이 논 문은 한계상태설계법에 의한 콘크리트 구조물의 설계 와 관련하여 구조물의 안전성에 목표를 둔 강도한계상 태와 함께 중요한 요소인 사용한계상태 검증 및 내구성 능 평가에서 핵심적인 역할을 하는 균열제어 규정의 설 계 실무 적용성을 파악하기 위한 것이다. 부착특성을 고려한 균열간격과 인장강화효과로부터 유도되는 철근 과 콘크리트의 평균변형률 차이의 곱으로부터 균열폭 을 계산하는 직접균열제어와 사용한계상태를 만족할 수 있는 허용균열폭을 이용한 계산식으로부터 유도되 는 최대철근간격 및 최대철근지름으로 정의되는 간접 균열제어를 함께 검토하였다. 이와 함께 콘크리트 구조 설계를 위한 또 다른 국내기준으로서 한계상태설계법 과는 다른 설계이론인 강도설계법을 기반으로 하는 2012년 개정 콘크리트구조기준의 균열폭 직접계산 및 간접균열제어 규정과 각각 비교를 실시하였다. 


\section{참고문헌}

1. KRTA. 2012. Korean Highway Bridge Design Code (Limit States Design Method). Seoul, Korea.

2. KRTA. 2014. Korean Highway Bridge Design Code (Limit States Design Method)-revised. Seoul, Korea.

3. KCI. 2012. Design Specifications for Structural Concrete, Kimoondang Publishing Co. Ltd., Seoul, Korea. p. 229-233.

4. ACI Committee 318. 2002. Building Code Requirement for Structural Concrete and Commentary (ACI 318-02), Farmington Hills, MI, USA.

5. CEB-FIP. 1991. CEB-FIP Model Code 1990, Comite Euro-International Du Beton, Switzerland.

6. CEN. 2002. Eurocode 2-Design of Concrete Structures, European Committee for Standardization, Brussels, Belgium.
7. Fib. 2010. Fib Model Code 2010, International Federation for Structural Concrete, Switzerland.

8. Lee, K. Y. and Kim, W. 2008. Analysis of crack width and deflection based on nonlinear bond characteristics in reinforced concrete flexural members. Journal of the Korea Concrete Institute. 20(4): 459-467.

9. Kim, W. 2014. Limit State Design of Concrete Structures. Donghwa Publishing Co. Ltd., Seoul, Korea.

10. KIBSE and KBDERC. 2015. Manual of Korean Highway Bridge Design Code(Limit States Design Method), Seoul, Korea.

11. KCI. 2012. Manual of Design Specifications for Structural Concrete, Kimoondang Publishing Co. Ltd., Seoul, Korea. 